\title{
Cigarette smoking and small irregular opacities
}

\author{
William Weiss *
}

\begin{abstract}
A survey of chemical workers by chest roentgenograms was designed to determine whether exposure to acrylic dust and/or cigarette smoking was associated with diffuse abnormalities suggestive of pneumoconiosis. The films were examined without knowledge of dust exposure or smoking habits. The International Labour Office (ILO) classification and standard films were used. Workers with exposure to asbestos were excluded. There was no relation between prevalence of abnormalities and exposure to dust. Among 181 workers 28 had s and/or t small irregular opacities with profusion of 0/1 (23), 1/0 (three), or 1/1 (two). These findings were present in $20 \%$ of smokers compared with $2 \cdot 2 \%$ of non-smokers. The prevalence increased with increasing age to 31.6\% among smokers aged 50-64. Prevalence was $10 \%$ among ex-smokers of cigarettes. Among current cigarette smokers, prevalence was $5.3 \%$ in those who smoked less than one pack per day, $31 \cdot 3 \%$ in heavier cigarette smokers, and $52.9 \%$ in 17 heavy cigarette smokers aged 50-64. Profusions of $0 / 1$ and $1 / 0$ are classified as "suspect" pneumoconiosis according to the ILO guidelines. The data in this sudy indicate that such abnormalities are directly related to age and smoking habits among workers not exposed to hazardous dust.
\end{abstract}

It is well established that cigarette smoke leads to pathological evidence of chronic inflammation, structural damage, and interstitial fibrosis in the lungs. These abnormalities are reflected in symptoms, physical signs, functional impairment, and radiographic abnormalities. It is agreed that the abnormalities are manifest in moderate to severe emphysema. The question as to whether diffuse pulmonary fibrosis caused by cigarette smoking can be detected radiographically has been debated in

^Emeritus Professor of Medicine, Hahnemann University, Philadelphia, PA, USA

W Weiss recent years. ${ }^{12}$ Unfortunately, there have been no substantial systematic studies of radiographicpathological correlations in the same subjects who are unexposed to fibrogenic dusts that could help to settle the issue. This problem is of some importance, in both the clinical and the medicolegal sense, because any increase in the normal lung markings on chest films may be interpreted as occupational disease, such as asbestosis, as a result of the substantial interobserver variation in readings. ${ }^{3}$

The present study is reported because there have been few radiographic investigations of people who are unexposed to fibrogenic dusts by smoking habits using the 1980 International Labour Office (ILO) classification and standard films with the reader(s) "blind" to smoking habits. The data are derived from a controlled study in which 100 workers exposed to acrylic dust were compared with 81 unexposed workers, all men matched by age, year hired, and smoking habit after exclusion of any workers with known exposure to asbestos. Sixteen and 15 per cent of each group respectively had "blind" reading classifications of $s / t$ small irregular opacities with profusion of $0 / 1$ or greater so the readings were examined by smoking habits.

\section{Method}

Routine periodic surveillance of workers in a chemical plant included $14 \times 17$ inch posteroanterior chest radiographs. Of 181 workers in this study, complete smoking histories were available for 163 with respect to type of tobacco used, current or previous cigarette smoking state, duration of cigarette smoking, and number of cigarettes smoked per day. Cigarette smokers were classified as exsmokers if they had not smoked for one year or more at the time of the examination.

Chest $x$ ray films were placed in alphabetical order by last name with identification obscured. They were read without any information regarding demographic characteristics, dust exposure, or smoking habits by the author. A form similar to that published by the National Institute of Occupational Safety and Health for reading according to the 1980 ILO classification ${ }^{4}$ was completed for each film using the standard films for comparison.

Statistical significance was evaluated by $\chi^{2}$ analysis. 
Table 1 Distribution of 181 workers by age and smoking habit

\begin{tabular}{llcc}
\hline Age & $\begin{array}{l}\text { Non-smokers } \\
\text { No(\%) }\end{array}$ & $\begin{array}{l}\text { Smokers } \\
\text { No(\%) }\end{array}$ & $\begin{array}{l}\text { Total } \\
\text { No }(\%)\end{array}$ \\
\hline $20-34$ & $19(41 \cdot 3)$ & $25(18 \cdot 5)$ & $44(24 \cdot 3)$ \\
$35-49$ & $10(21 \cdot 7)$ & $53(39 \cdot 3)$ & $63(34 \cdot 8)$ \\
$50-64$ & $17(37 \cdot 0)$ & $57(42 \cdot 2)$ & $74(40 \cdot 9)$ \\
Total & $46(100 \cdot 0)$ & $135(100 \cdot 0)$ & $181(100 \cdot 0)$ \\
\hline
\end{tabular}

\section{Results}

Table 1 gives the distribution of the 181 workers by age and smoking habit. Comparing smokers and nonsmokers by age showed differences that were statistically significant $\left(\chi^{2}=10.59\right.$, df $\left.=2, \mathrm{p}<0.01\right)$. Therefore, age specific rates are used to compare smoking groups with regard to radiographic findings.

Film quality according to the ILO classification did not differ significantly between smokers and nonsmokers (table 2) $\left(\chi^{2}=0.23, \mathrm{df}=2, \mathrm{p}>0.50\right)$.

Among the 181 radiographs, 28 were classified as type $s$ and/or $t$ with profusion of $0 / 1$ or greater. Twenty three were $0 / 1$, three were $1 / 0$, and two were $1 / 1$. Only one $(2 \cdot 2 \%)$ of the 46 non-smokers but 27 $(20 \%)$ of the smokers were classified $0 / 1$ or greater (table 3), a difference which was statistically highly significant $\left(\chi^{2}=8.34, \mathrm{df}=1, \mathrm{p}<0.005\right)$. All five films with profusion of $1 / 0$ or $1 / 1$ occurred among the smokers. The prevalence rate increased steadily with increasing age among smokers to a maximum of $32 \%$ for those aged 50-64 ( $\chi^{2}$ for trend $=9 \cdot 57, \mathrm{df}=2$, $\mathrm{p}<0.01$ ).

The smokers were stratified into current cigarette users, ex-smokers of cigarettes, and a miscellaneous category including 12 cigarette smokers of unknown amount and six pipe or cigar smokers (table 4). The current cigarette smokers were further subdivided into light (less than one pack per day) and heavy (one pack or more per day). Because the mean age at which cigarette smoking began in this population was $18 \cdot 1$ years among current light smokers and 16.4 years among current heavy smokers, duration of current cigarette smoking was not considered as a factor in degree of consumption. In effect, age at the time of the survey was a surrogate for duration of cigarette smoking.

Table 2 Distribution of 181 workers by chest film quality and smoking habit

\begin{tabular}{llcc}
\hline Film quality & $\begin{array}{l}\text { Non-smokers } \\
\text { No(\%) }\end{array}$ & $\begin{array}{l}\text { Smokers } \\
\text { No(\%) }\end{array}$ & $\begin{array}{l}\text { Total } \\
\text { No (\%) }\end{array}$ \\
\hline 1 & $31(67 \cdot 4)$ & $87(64 \cdot 4)$ & $118(65 \cdot 2)$ \\
2 & $13(28 \cdot 3)$ & $43(31.9)$ & $56(30.9)$ \\
3 & $2(4 \cdot 3)$ & $5(3.7)$ & $7(3.9)$ \\
Total & $46(100 \cdot 0)$ & $135(100 \cdot 0)$ & $181(100 \cdot 0)$ \\
\hline
\end{tabular}

Table 3 Prevalence of small irregular opacities $(S I O \geqslant 0 / 1)$ among 181 workers by age and smoking habit

\begin{tabular}{|c|c|c|c|c|}
\hline \multirow[b]{2}{*}{ Age } & \multicolumn{2}{|c|}{ Non-smokers } & \multicolumn{2}{|c|}{ Smokers } \\
\hline & $\begin{array}{l}\text { No in } \\
\text { group }\end{array}$ & $\begin{array}{l}\text { SIO } \\
\text { No }(\%)\end{array}$ & $\begin{array}{l}\text { No in } \\
\text { group }\end{array}$ & $\begin{array}{l}\text { SIO } \\
\text { No }(\%)\end{array}$ \\
\hline $\begin{array}{l}20-34 \\
35-49 \\
50-64\end{array}$ & $\begin{array}{l}19 \\
10 \\
17\end{array}$ & $\begin{array}{l}0(-) \\
1(10 \cdot 0) \\
0(-)\end{array}$ & $\begin{array}{l}25 \\
53 \\
57\end{array}$ & $\begin{array}{c}1(4 \cdot 0) \\
8(15 \cdot 1) \\
18(31 \cdot 6)\end{array}$ \\
\hline Total & 46 & $1(2 \cdot 2)$ & 135 & $27^{\star}(20.0)$ \\
\hline
\end{tabular}

*Includes three with profusion of $1 / 0$ and two with profusion of $1 / 1$.

Note: \% not calculated when denominator is less than 10.

Among current cigarette smokers, only one (5\%) of 19 light smokers but $15(31 \%)$ of 48 heavy smokers had profusion of $0 / 1$ or greater. Among the heavy smokers prevalence increased with increasing age and reached 53\% among 17 men aged 50-64. Exsmokers of cigarettes had a low prevalence $(10 \%)$ whereas the miscellaneous group had a high prevalence similar to that of the heavy current cigarette smokers.

\section{Discussion}

It has been recognised for decades that chronic bronchitis, most of which is caused by cigarette smoking, is associated with diffuse lung abnormalities on chest roentgenograms. In a cohort study of chronic bronchitis begun in 1958, Bates et al ${ }^{5}$ included a chest $x$ ray film classification " $c$ " defined as "dirty" chest or increase of peripheral markings. Ninety nine per cent of the 216 men were smokers and all but 10 of the smokers had used cigarettes; $17.9 \%$ of the films were classified as " $c$ ". General accentuation of linear markings throughout the lungs in both chronic bronchitis and emphysema was also described by Fraser and Paré in their 1970 text book. ${ }^{6}$

In 1973 Morgan et $a l^{7}$ noted that as people age chest $x$ ray film abnormalities develop that may be confused with those of pneumoconiosis, especially in heavy smokers. It seems likely that the increased frequency of these changes with aging in smokers may be a function of cumulative smoke exposure.

The guidelines for the use of the ILO classification of radiographs for pneumoconiosis ${ }^{4}$ indicate that the classification should be applied if any parenchymal appearances are consistent with pneumoconiosis. Although the standard films that go with the classification were chosen to represent midpoints of the major profusion categories, profusion may be classified into 12 minor categories. The guidelines say that a profusion of $0 / 1$ means a choice of the 0 category but category 1 was seriously considered whereas a profusion of $1 / 0$ means a choice of category 1 but category 0 was seriously considered. They further 
Table 4 Prevalence of small irregular opacities (SIO $\geqslant 0 / 1)$ among 135 smokers by age and detailed smoking habits

\begin{tabular}{|c|c|c|c|c|c|c|c|c|}
\hline \multirow[b]{3}{*}{ Age } & \multicolumn{4}{|c|}{ Current cigarette smokers } & \multirow{2}{*}{\multicolumn{2}{|c|}{ Ex-smokers of cigarettes }} & \multirow{2}{*}{\multicolumn{2}{|c|}{$\begin{array}{l}\text { Unknown amount and } \\
\text { other smokers }\end{array}$}} \\
\hline & \multicolumn{2}{|c|}{$<1$ pack } & \multicolumn{2}{|c|}{$\geqslant 1$ packs } & & & & \\
\hline & $\begin{array}{l}\text { No in } \\
\text { group }\end{array}$ & $\begin{array}{l}\text { SIO } \\
\text { No }(\%)\end{array}$ & $\begin{array}{l}\text { No in } \\
\text { group }\end{array}$ & $\begin{array}{l}\text { SIO } \\
\text { No }(\%)\end{array}$ & $\begin{array}{l}\text { No in } \\
\text { group }\end{array}$ & $\begin{array}{l}\text { SIO } \\
\text { No }(\%)\end{array}$ & $\begin{array}{l}\text { No in } \\
\text { group }\end{array}$ & $\begin{array}{l}\text { SIO } \\
\text { No }(\%)\end{array}$ \\
\hline $\begin{array}{l}20-34 \\
35-49 \\
50-64\end{array}$ & $\begin{array}{l}6 \\
6 \\
7\end{array}$ & $\begin{array}{l}0(-) \\
0(-) \\
1(-)\end{array}$ & $\begin{array}{l}10 \\
21 \\
17\end{array}$ & $\begin{array}{l}1(10 \cdot 0) \\
5(23 \cdot 8) \\
9(52.9)^{\star}\end{array}$ & $\begin{array}{r}6 \\
21 \\
23\end{array}$ & $\begin{array}{l}0(-) \\
0(0 \cdot 0) \\
5(22 \cdot 7) \dagger\end{array}$ & $\begin{array}{r}3 \\
5 \\
10\end{array}$ & $\begin{array}{l}0(-) \\
3(-)^{\star} \\
3(30 \cdot 0)\end{array}$ \\
\hline Total & 19 & $1(5 \cdot 3)$ & 48 & $15(31 \cdot 3)$ & 50 & $5(10 \cdot 0)$ & $18 \ddagger$ & $6(33.0)$ \\
\hline
\end{tabular}

$\star$ Includes one reading of $1 / 0$ and one of $1 / 1$.

tIncludes one reading of $1 / 0$.

Includes six pipe/cigar smokers, three of whom had readings of $0 / 1$.

Note: \% not calculated when denominator is less than 10 .

state that categories $0 / 1$ and $1 / 0$ may represent "suspect" pneumoconiosis (see ${ }^{4}$ note 8 , page 14).

Unfortunately, inter and intraobserver variation complicates the application of the ILO classification. Morgan $e t \mathrm{al}^{7}$ postulated a substantial overlap in the readings of normal films and of those with pneumoconiosis on the ILO scale of profusion. The extent of interobserver variation has been documented in a number of studies ${ }^{37-11}$ and it increases with decreasing proficiency of the readers. ${ }^{8}$ In the " $B$ " reader examination $71 \%$ of successful candidates had a corrected reading error for small opacity profusion of more than one minor category and $100 \%$ of unsuccessful candidates had such errors. ${ }^{8}$

In 1986 the American Thoracic Society adopted the criterion of a profusion of $1 / 1$ or greater for the diagnosis of asbestosis. ${ }^{12}$ This serves to minimise both the problem of observer variation in the dichotomy of normal or abnormal and the difficulty of distinguishing between smoking related abnormalities and asbestosis. The present study of chemical workers was carried out with one reader so it does not take into account reader variation.

Although there is good histological evidence showing that interstitial pulmonary fibrosis and bronchiolar wall fibrosis are part of the effect of cigarette smoking, ${ }^{1314}$ a major issue is the question as to what pathological abnormalities are represented by the diffuse radiographic changes in smokers referred to as "dirty" chest or borderline classifications $(0 / 1$ and 1/0) of small irregular opacities (SIO).

Radiographic-pathological correlation studies are required to answer this question but few have been done. Feigin and Abraham ${ }^{15}$ published an abstract of a small study and concluded that increased markings on chest $x$ ray films appear to represent oedema, infiltration, and possibly fibrosis in the perivenous connective tissue but a complete report has not been published. Cockroft $e t$ al $^{16}$ found that in 16 men SIO were associated with histological scores of both emphysema and of interstitial fibrosis. The evidence is limited. More and larger studies are needed.
Blanc and Gamsu $^{17}$ have recently considered whether cigarette smoking causes radiographic opacities consistent with pneumoconiosis. They restricted their review to published studies using the ILO classification because it promotes better comparisons between different investigations despite observer variability, lack of specificity, and its semiquantitative nature. As a result of five studies cited, they concluded that cigarette smoking alone is not associated with radiographic opacities consistent with pneumoconiosis.

They cited a report by Castellan et al ${ }^{18}$ as the most convincing study. These investigators surveyed 1422 blue collar workers who had had no exposure to known respiratory hazards. The chest $x$ ray films were evaluated independently by three " $B$ " readers and the readings were "blind" to the characteristics of the workers, including their smoking habits. The median reading of profusion was the summary reading for small opacities. SIO of profusion $0 / 1$ or greater were statistically associated with age, sex, and pack-years of smoking based on eight cases. As there was only one subject with a profusion of $1 / 0$, they concluded that using the median of three independent readings should rarely result in an interpretation of chest radiographs as "positive" for pneumoconiosis. Two problems ensue, however, with this conclusion. Firstly, $82 \%$ of the surveyed people were less than 45 years old (RM Castellan, personal communication, 10 June 1985). Secondly, of the seven people with median readings of $0 / 1$, three had a higher reading of $1 / 0$ and one had a higher reading of $1 / 1$. Thus if films are examined by only a single reader, the usual case in practice, the results might be different. It should be noted that seven of the eight people with profusion of $0 / 1$ or greater were cigarette smokers.

Blanc and Gamsu' ${ }^{17}$ also cited Kilburn et al, ${ }^{19}$ Cooper and Sargent, ${ }^{20}$ Crosbie, ${ }^{21}$ and Epstein et al ${ }^{22}$ as favouring their conclusion. Kilburn et al ${ }^{19}$ studied a random sample of the Michigan population and a census tract in Long Beach, California, but the results were not stratified by smoking habit. The 
investigation by Cooper and Sargent ${ }^{20}$ was a survey of 152 perlite workers of whom 14 had small opacities with profusion of $0 / 1$ but no association with smoking habits was examined because smoking information was incomplete (WC Cooper, personal communication, 1 May 1986). Crosbie ${ }^{21}$ examined chest $x$ ray films of 935 workers in 11 plants with exposure to carbon black; only six had readings of $1 / 0$ to $1 / 2$ but most of the workers had been volunteers for the examination and no smoking information or age stratification in relation to the results was provided. Epstein et al $^{22}$ studied the chest $x$ ray films of 200 admissions to an urban university hospital without known industrial exposure and $27(13.5 \%)$ had SIO with profusion of $1 / 0$ or greater; unfortunately, smoking habits were obtained only for those with SIO and not those without SIO. It appears that the evidence cited by Blanc and Gamsu ${ }^{17}$ was limited in several ways.

A further report, by Peilian $e t a l,{ }^{23}$ used a method similar to that in the present paper. They examined 140 cotton textile workers in China who had worked in the preparatory area of mills for at least 20 years and 140 healthy controls with no dust exposure, matched by age, sex, and smoking history. They used the ILO classification "blindly" and abnormal findings were defined as profusion of $1 / 0$ or greater. No statistically significant difference was found between cotton workers and controls so they combined both groups to examine the results in relation to smoking habit. There was a highly significant difference in the prevalence of radiographic abnormalities; $33.3 \%$ of 96 smokers compared with $6.5 \%$ of non-smokers. Among the controls alone the figures were $27.2 \%$ of 48 smokers compared with $4.3 \%$ of 92 non-smokers. These results are similar to those in table 3 but are based on higher levels of profusion, perhaps due to interobserver variation between Peilian et $a l^{23}$ and myself.

Limited studies suggest that a diffuse $x$ ray abnormality exists in some smokers that is similar to SIO and may be interpreted as pneumoconiosis. This abnormality occurs in low profusion with a prevalence that is dose related to cigarette smoking. As well as the ILO classification, further investigation of this issue should be based if possible on "blind" readings by multiple readers, should include a substantial number of people over age 45 , and should include profusion readings of $0 / 1$ and the range in readings if more than one observer is used so that some approximation of reality can be realised.

I am grateful to Lester De Fonso, BS, statistician, Rohm and Haas Co, for assistance in this study.

Requests for reprints to Professor William Weiss, MD, 3912 Netherfield Road, Philadelphia, PA 19129, USA.
1 Weiss W. Smoking and pulmonary fibrosis. J Occup Med 1988;30:33-9.

2 Blanc PD, Gamsu G. The effect of cigarette smoking on the detection of small radiographic opacities in inorganic dust diseases. J Thorac Imaging 1988;3:51-6.

3 Rossiter CE, Browne K, Gilson JC. International classification trial of AIA set of 100 radiographs of asbestos workers. $\mathrm{Br} \mathrm{J}$ Ind Med 1988;45:538-43.

4 International Labour Organisation. Guidelines for the use of ILO international classification of radiographs for pneumoconioses, revised edition. Geneva: ILO, 1980.

5 Bates DV, Gordon CA, Paul GI, Place REG, Snidal DP, Woolf CR. Chronic bronchitis: report of the third and fourth stages of the co-ordinated study of chronic bronchitis in the Department of Veterans Affairs, Canada. Medical Services Journal of Canada 1966;XXII:5-54.

6 Fraser RG, Paré JAP. Diagnosis of diseases of the chest. Philadelphia: WB Saunders Co, 1970, 991 and 1008.

7 Morgan RH, Donner MW, Gayler BW, Margulies SI, Rao PS, Wheeler PS. Decision processes and observer error in the diagnosis of pneumoconiosis by chest roentgenography. American Journal of Roentgenology, Radium Therapy and Nuclear Medicine 1973;117:757-64.

8 Morgan RH. Proficiency examination of physicians for classifying pneumoconiosis chest films. American Journal of Roentgenology, Radium Therapy and Nuclear Medicine 1979;132: 803-8.

9 Werner JB. Problems with the measurement of radiological change. In: Wagner JC, ed. Biological effects of mineral fibres. Lyon: International Agency for Research on Cancer, 1980: 571-7. (IARC sci Publ No 30.)

10 Zoloth S, Michaels D, Lacher M, et al. Asbestos disease screening by non-specialists: results of an evaluation. $A m \mathrm{~J}$ Public Health 1986;76:1392-5.

11 Ducatman AM, Yang WN, Forman SA. "B-readers" and asbestos medical surveillance. J Occup Med 1988;30:644-7.

12 American Thoracic Society Statement: the diagnosis of nonmalignant diseases related to asbestos. Am Rev Respir Dis 1986;134:363-8.

13 Johansson LG, Albin MP, Jakobsson KM, Welinder HEC, Ranstam PJ, Attewell RG. Ferruginous bodies and pulmonary fibrosis in dead low to moderately exposed asbestos cement workers: histological examination. $\mathrm{Br} J$ Ind Med 1987;44: 550-8.

14 Adesina AM, Vallyathan V, McQuillen EN, Weaver SO, Craighead JE. Bronchiolar inflammation and fibrosis associated with smoking; a morphologic cross-sectional population analysis. Am Rev Respir Dis 1991;143:144-9.

15 Feigin DS, Abraham JL. "Increased pulmonary markings"-a radiologic-pathologic correlation study. Invest Radiol 1980;15:425

16 Cockcroft AE, Wagner JC, Seal EM, et al. Irregular opacities in coal workers' pneumoconiosis. Correlation with pulmonary function and pathology. In: Walton $\mathrm{EH}$, ed. Inhaled particles $V$. New York: Pergamon Press, 1982:767-84.

17 Blanc PD, Gamsu G. Cigarette smoking and pneumoconiosis: structuring the debate (editorial). $A m J$ Ind Med 1989;16:1-4.

18 Castellan RM, Sanderson WT, Petersen MR. Prevalence of radiographic appearance of pneumoconiosis in an unexposed blue collar population. Am Rev Respir Dis 1985;131:684-6.

19 Kilburn KH, Lilis R, Anderson HA, Miller A, Warshaw RH. Interaction of asbestos, age, and cigarette smoking in producing radiographic evidence of diffuse pulmonary fibrosis. $A m \mathrm{~J}$ Med 1986;80:377-81.

20 Cooper WC, Sargent EN. Study of chest radiographs and pulmonary ventilatory function in perlite workers. $J$ Occup Med 1986;28:199-206.

21 Crosbie WA. The respiratory health of carbon black workers. Arch Environ Health 1986;41:346-53.

22 Epstein DM, Miller WT, Bresnitz EA, Levine MS, Gefter WB. Application of ILO classification to a population without industrial exposure: findings to be differentiated from pneumoconiosis. American Journal of Roentgenology, Radium Therapy and Nuclear Medicine 1984;142:53-8.

23 Peilian L, Yingzhing H, Naiyi S, et al. Radiographic findings in cotton textile workers and the relationship to cigarette smoking. Regul Toxicol Pharmacol 1986;6:60-5.

Accepted 10 June 1991 